\title{
Nerve Growth Factor Increases the Number of Functional Na Channels and Induces TTX-Resistant Na Channels in PC12 Pheochromocytoma Cells
}

\author{
B. Rudy, ${ }^{1}$ B. Kirschenbaum, ${ }^{1}$ A. Rukenstein, ${ }^{2}$ and L. A. Greene ${ }^{2}$ \\ Departments of 'Physiology and PPharmacology, New York University Medical Center, New York, New York 10016
}

The PC12 clone is a line of rat pheochromocytoma cells that undergoes neuronal differentiation in the presence of NGF protein. In the absence of NGF, PC12 cells are electrically inexcitable, while after several weeks of NGF treatment they develop $\mathrm{Na}^{+}$action potentials. Past estimates made by measuring binding of ${ }^{3} \mathrm{H}$-saxitoxin (STX) indicate that NGF treatment brings about a large increase in $\mathrm{Na}$ channel density that is of sufficient magnitude to account for the induction of excitability. We have now used ${ }^{22} \mathrm{Na}$ uptake to measure the Na permeability of PC12 cells before and after long-term NGF treatment. Treatment with NGF does not change the resting $\mathrm{Na}^{+}$permeability. The alkaloid toxins veratridine and batrachotoxin (BTX) and scorpion toxin were used to activate $\mathrm{Na}$ channels. Such studies demonstrate that these toxins induce TTX-sensitive Na uptake in both NGF-treated and untreated cells and reveal differences in functional $\mathrm{Na}$ channel numbers per cell and per unit of membrane area that are similar to those found in the STX binding studies. On the other hand, affinities for drugs that activate these channels are not affected by NGF treatment. We also find that NGF. treated PC12 cells contain a population of $\mathrm{Na}$ channels with low affinity for TTX. These channels account for $5-20 \%$ of total BTX or veratridine-stimulated flux. Thus, NGF has 2 effects regarding the $\mathrm{Na}$ channels of PC12 cells: it increases the number of functional $\mathrm{Na}$ channels that otherwise behave similarly to those present before NGF treatment, and it induces the presence of TTX-resistant Na channels. These findings indicate that the PC12 model system may serve to study the developmental regulation of $\mathrm{Na}$ channel expression and properties.

The PC 12 clonal cell line of rat pheochromocytoma cells undergoes a neuronlike differentiation when grown in the presence of NGF protein (Greene and Tischler, 1976, 1982; Dichter et al., 1977). For instance, when grown in NGF, PCl 2 cells cease to

\footnotetext{
Received Nov. 7, 1985; revised June 30, 1986 and Sept. 29, 1986; accepted Nov. $17,1986$.

This research was supported in part by United States Public Health Service Research Grants, GM 26976 to B.R., and NS16036 to L.A.G., and a March-ofDimes Birth Defects Foundation Research Grant to L.A.G. B.R. and L.A.G. are career Development Awardees of the Ira T. Hirschl Trust. We thank Dr. John Daly, Laboratory of Chemistry, NIAMDD, National Institutes of Health, who kindly provided batrachotoxin. We would also like to thank Miss Catherine Malichio for her excellent secretarial assistance.

Correspondence should be addressed to Dr. B. Rudy, Department of Physiology New York University Medical Center, 550 First Avenue, New York, NY 10016.
} Copyright (C) 1987 Society for Neuroscience $0270-6474 / 87 / 061613 \cdot 13 \$ 02.00 / 0$ divide, and extend long neuritelike processes. Moreover, prior to treatment with NGF, PC12 cells cannot sustain action potentials, while after several weeks of exposure to the factor they become capable of producing $\mathrm{Na}^{+}$-dependent action potentials (Dichter et al., 1977; Rudy et al., 1982). Thus, these cells provide a model for the means by which developing neurons acquire electrical excitability. Rudy et al. (1982) have shown that longterm NGF exposure increases the number of $\mathrm{Na}$ channels in PC1 2 cultures by 15 - to 25 -fold per cell and by $6-$ to 9 -fold/mg protein, as determined by hinding of the channel blocker saxitoxin (STX). This increase appeared to be sufficient to account for the induction of excitability by NGF. These studies, however, do not provide information on the functional properties of the binding sites. It was not known, for instance, if the STX binding sites present in PC1 2 cells grown without NGF represent active Na channels. For instance, O'Lague et al. (1985) reported that they were unable to detect, by means of voltage-clamp recording, any $\mathrm{Na}$ currents in $\mathrm{PC} 12$ cells grown in the absence of NGF. These studies raised the possibility that the STX binding sites present before NGF treatment are nonfunctional. In addition, it has not been clear whether all of the NGF-induced STX binding sites could necessarily be equated with functional channels. Such information is important if the PC12 model is to be used to study the development of $\mathrm{Na}$ channels.

It is also important to determine whether NGF produces any qualitative changes in the properties of $\mathrm{Na}$ channels (maturation). Such qualitative changes have been observed in other developing excitable systems. For example, Baumgold et al. $(1983 \mathrm{a}, \mathrm{b})$ have suggested that in developing chick skeletal muscle cultures, a nonfunctional form of the $\mathrm{Na}$ channel appears first. These channels are not activated by the $\mathrm{Na}$ channel activator BTX, but they can be activated in the presence of scorpion toxin. On this basis, Baumgold et al. $(1983 \mathrm{a}, \mathrm{b})$ have proposed that an immature form of the $\mathrm{Na}$ channel appears first that can be "unmasked" by scorpion toxin.

The experiments reported here were carried out to study the changes in $\mathrm{Na}$ permeability that result from exposure of cells to NGF and to make quantitative determinations of the functionality of the Na channels detected by STX binding assays. ${ }^{22} \mathrm{Na}$ uptake was used to study membrane $\mathrm{Na}$ permeability and channel function. The alkaloid toxins veratridine and BTX, which are known to produce persistent activation of the voltagedependent Na channel, and scorpion or anemone toxins, which act cooperatively with the alkaloid toxins to activate channels (Catterall, 1980), were used. With their aid, Na flux measurements permitted the study of 3 different sites on the Na channel 


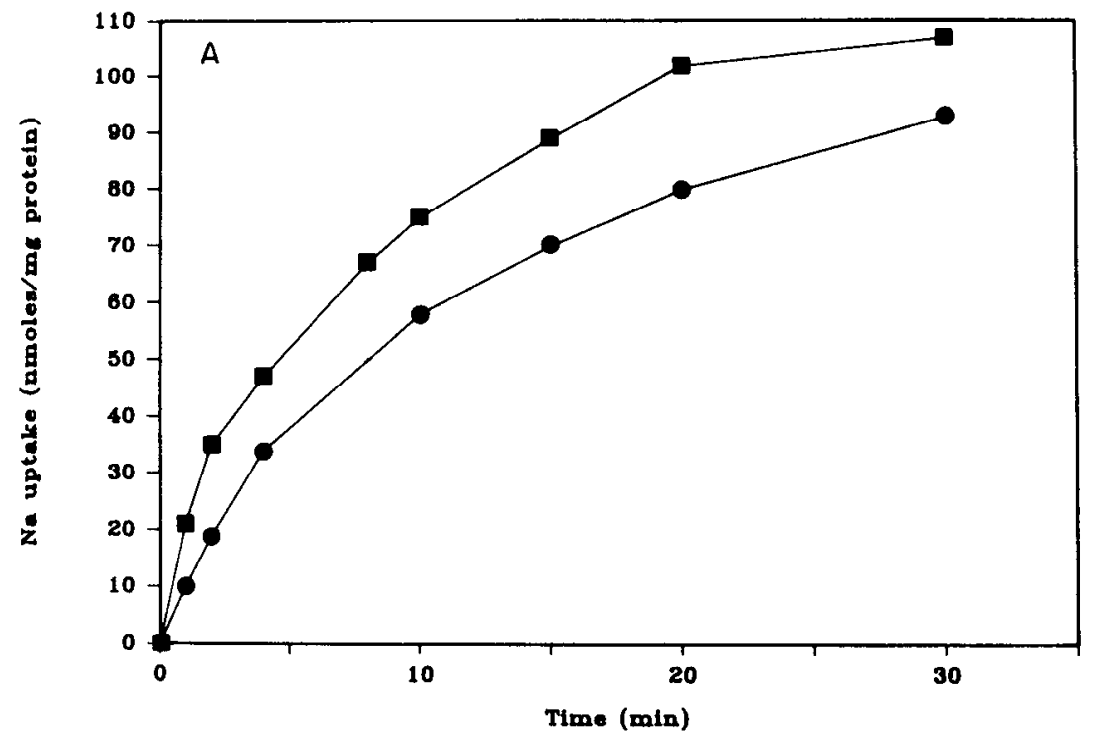

Figure 1. Stimulation of ${ }^{22} \mathrm{Na}$ uptake of $\mathrm{PCl} 2$ cells by veratridine. NGF-untreated PC12 cells $(A)$ and NGF-treated PC 12 cells $(B)$ were incubated for 20 $\min$ in the presence $(\boldsymbol{D})$ or absence $(\mathbf{C})$ of $100 \mu \mathrm{M}$ veratridine in Na-free medium and assayed for the indicated times in assay solution containing $50 \mathrm{~mm} \mathrm{Na}$ $10 \mu \mathrm{Ci}$ of ${ }^{22} \mathrm{Na}$, and with or without veratridine.

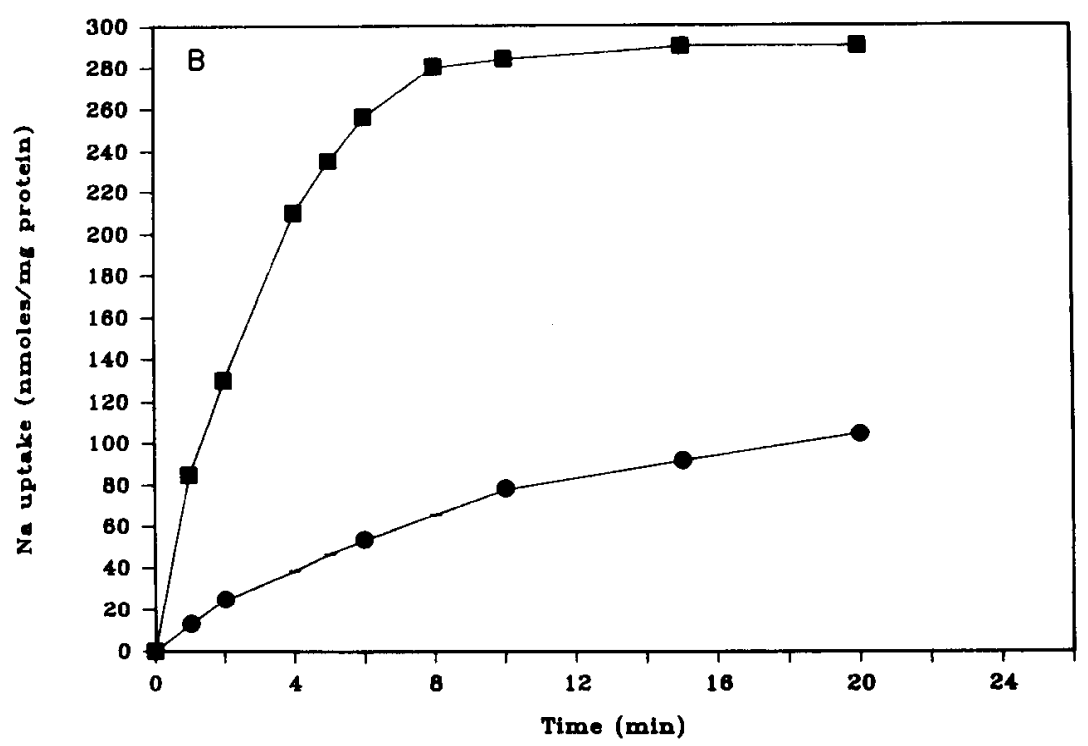

molecule: the TTX and STX binding site, the alkaloid toxins binding site, and the scorpion or anemone toxin binding site. In this manner, we explored whether any of these 3 sites is altered by NGF treatment. Our findings indicate that the effects of NGF on PC1 2 cell excitability and STX binding are correlated with an increase in the membrane density of functional $\mathrm{Na}^{+}$ channels. Moreover, while NGF does not appear to change at least several properties of PC1 2 cell $\mathrm{Na}$ channels, it does induce a population of $\mathrm{Na}$ channels resistant to TTX.

\section{Materials and Methods}

Materials. Chemicals were obtained from the following sources: TTX, scorpion venom and Triton X-100 from Sigma, veratridine from Aldrich, and choline chloride from Eastman. All other chemicals were reagent grade. BTX was kindly provided by Dr. John Daly, Laboratory of Chemistry, NIAMDD, National Institutes of Health. Millipore Super Q purified water was used throughout.

Scorpion toxin was purified from crude scorpion venom by an adaptation of the methods of Catterall $(1976,1977 \mathrm{~b})$ and Okamoto (1980). In brief, $25 \mathrm{mg}$ of venom was dissolved in water at $0^{\circ} \mathrm{C}$ and maintained at this temperature for $1 \mathrm{hr}$. The mixture was centrifuged at $4^{\circ} \mathrm{C}$ at $16,000 \times g$ for $15 \mathrm{~min}$. The supernatant, which contains about $10 \%$ of the total starting protein, was applied to a CM-Sephadex column equilibrated in $10 \mathrm{~mm}$ ammonium acetate (pH 5.5). After an extensive wash with this buffer, the column was eluted with a linear gradient of ammonium acetate $(10 \mathrm{mM}, \mathrm{pH} 5.5$, to $1 \mathrm{M}, \mathrm{pH} 7)$. The peaks were assayed for toxin activity by their effects on frog sartorius muscle. The active fraction, which contains $\sim 10 \%$ of the applied protein, was pooled and reapplied to the same column and eluted with an expanded gradient $(0.5-0.8 \mathrm{M}$ ammonium acetate, $\mathrm{pH} 7)$. A single band of $M_{r} \sim 7000$ was detected by electrophoresis in a urea/ $\beta$-alanine/acetate system (Catterall, 1976).

Culture of cells. PC12 cells were grown as previously described (Greene and Tischler, 1976; Rudy et al., 1982). For most of the experiments reported here, NGF-treated cells were prepared as follows: Cells were grown in the presence of NGF (Mobley et al., 1976) at a final concentration of $50 \mathrm{ng} / \mathrm{ml}$ for at least 2 weeks on collagen-coated dishes and then resuspended, replated on polyornithine-coated $18 \mathrm{~mm}$ multiwell dishes (Letourneau, 1975; Rudy et al., 1982) and incubated in the presence of NGF for an additional $24-48 \mathrm{hr}$ period. Under such conditions of high substrate adhesivity, these cells do not regenerate substantial neurites during this time, and hence the membrane area can be readily estimated (Rudy et al., 1982). Cultures of non-NGF-treated cells were similarly prepared, but without NGF at any step. Intracellular recording, cell counts, protein determination, and estimation of cell membrane area were carried out as previously described (Rudy et al., 1982).

Measurement of ${ }^{22} \mathrm{Na}$ uptake. Rates of ${ }^{22} \mathrm{Na}$ uptake were measured as described by Catterall (1975a, b) for neuroblastoma cells in monolayer culture. Prior to assay, cells were preincubated with effectors at $36^{\circ} \mathrm{C}$ in a $\mathrm{Na}^{+}$-free medium containing (unless otherwise noted) $50 \mathrm{~mm}$ TrisHEPES (pH 7.4), $260 \mathrm{~mm}$ sucrose or $130 \mathrm{~mm}$ choline chloride, $5.4 \mathrm{~mm}$ 


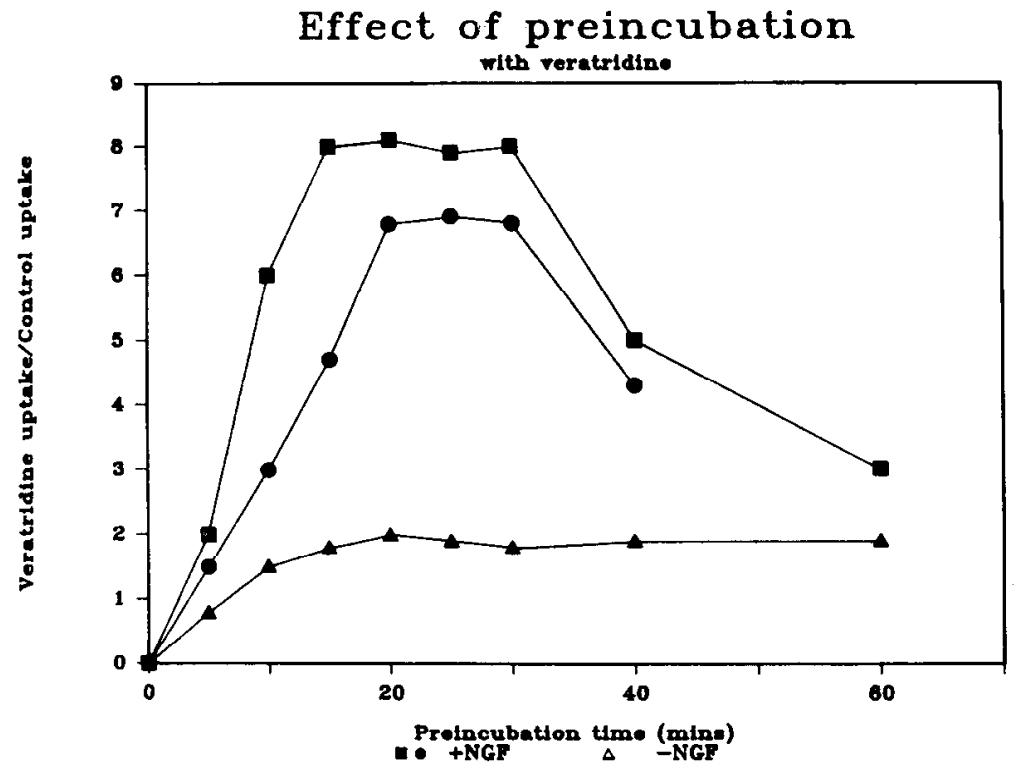

Figure 2. Veratridine-stimulated ${ }^{22} \mathrm{Na}$ uptake in NGF-untreated ( $(\Delta)$ and NGFtreated PC12 cells (Expt. 12-22-82, $\mathbf{\square}$; Expt. 12-1-82, ๑). PC12 cells were incubated for the indicated times in $\mathrm{Na}$ free medium in the presence of $100 \mu \mathrm{M}$ veratridine and assayed in $50 \mathrm{~mm} \mathrm{Na}$ assay medium for $30 \mathrm{sec}$. Data are shown as the ratio of ${ }^{22} \mathrm{Na}$ uptake in the presence of veratridine to the uptake in control cultures incubated and assayed in the absence of veratridine.

$\mathrm{KCl}, 1.8 \mathrm{mM} \mathrm{CaCl}_{2}, 0.8 \mathrm{mM} \mathrm{MgSO}_{4}$, and $5.5 \mathrm{~mm}$ glucose to allow equilibration with effectors without increasing internal $\mathrm{Na}^{+}$. Uptake measurements were initiated by removal of this medium and addition of assay solution at $36^{\circ} \mathrm{C}$ containing $5 \mathrm{~mm}$ ouabain to inhibit $\mathrm{Na}$ extrusion via the $\mathrm{Na}-\mathrm{K}$ pump, $5-10 \mu \mathrm{Ci}$ of carrier-free ${ }^{22} \mathrm{NaCl}$ (New England Nuclear) and the indicated effectors. Assay medium contained (unless otherwise noted) 5-50 mM NaCl, $50 \mathrm{~mm}$ Tris-HEPES (pH 7.4), $5.4 \mathrm{~mm} \mathrm{KCl}, 0.8 \mathrm{mM} \mathrm{MgSO}_{4}, 1.8 \mathrm{mM} \mathrm{CaCl}_{2}, 5.5 \mathrm{~mm}$ glucose, and 96$140 \mathrm{~mm}$ (depending on the Na concentration) Tris- $\mathrm{Cl}(\mathrm{pH} \mathrm{7.4)}$ or 80 $120 \mathrm{~mm}$ choline chloride. Uptake was terminated by removing the radioactive solution and washing 3 times at room temperature and within $15 \mathrm{sec}$ with a washing solution containing $164 \mathrm{~mm}$ choline chloride, $0.8 \mathrm{~mm} \mathrm{MgSO}_{4}, 1.8 \mathrm{~mm} \mathrm{CaCl}_{2}, 2 \mu \mathrm{M}$ TTX, and $5 \mathrm{~mm}$ Tris-HEPES $(\mathrm{pH}$ 7.4). Cells were resuspended in Triton X-100 as described previously (Rudy et al., 1982), and radioactivity was measured in a Beckman $\gamma$-counter. The figures and tables show single experiments or the average of several independent experiments, as noted in the legends. However, in each experiment, 5-6 replicate cultures were assayed under each condition. The variation in the data is shown only in Figure 3, but was very similar in all experiments.

\section{Results}

Na uptake in PC12 cells and stimulation by veratridine

Passive $\mathrm{Na}$ permeability and the activation of $\mathrm{Na}$ channcls by alkaloid neurotoxins were measured in PC1 2 cells by the method of Catterall (1975a, b). Passive $\mathrm{Na}$ influx was measured in cells in which the active extrusion of $\mathrm{Na}$ was blocked by 5 mм ouabain. Under these conditions, and in the presence of $50 \mathrm{~mm}$ external $\mathrm{Na}$, $\mathrm{Na}$ uptake follows a logarithmic time course with a $t_{1 / 2}$ of 15-25 min in NGF-untreated cells and 35-50 min in NGF-treated cells (Fig. 1, $A, B$ ). At equilibrium the internal $\mathrm{Na}$ concentration equals the external concentration.

Persistent alkaloid activators of the $\mathrm{Na}$ channel probably work by interacting with a receptor localized inside the cell membrane (Hille, 1984). This may explain why, in order to study ion fluxes through drug-activated channels, it is necessary to preequilibrate the cells with the drugs of interest for relatively long periods of time. This allows the drug to permeate the lipid bilayer and equilibrate with its receptor. Catterall (1975a, b, 1976), whose technique was applied to our studies, preincubated cultured murine neuroblastoma cells for $30 \mathrm{~min}$ to allow for drug equilibration. Since PC12 cells are much smaller than neuroblastoma cells, even after they double in size in response to NGF, we assumed that similar times would be sufficient and used $30-60$ min preincubation in initial studies. Results with NGF-treated cells, however, demonstrated large variations in the degree of $\mathrm{Na}$ flux stimulation by veratridine. They often also showed a much smaller stimulation than that expected from the number of $\mathrm{Na}$ channels in the cells as estimated from STX binding experiments.

We therefore explored in detail $\mathrm{Na}$ influx as a function of preincubation time with veratridine. Figure 2 shows the rate of $\mathrm{Na}$ influx in NGF-treated PC12 cell cultures in a 30 sec uptake experiment as a function of preincubation time with $100 \mu \mathrm{M}$ veratridine. The data show that $\mathrm{Na}$ uptake increases as the preincubation time is increased up to $15-20 \mathrm{~min}$. The rate of influx attained reaches a plateau around 15-30 min and then decreases. Because of this drop-off, we chose 20 min of prcincubation for all subsequent experiments with $100 \mu \mathrm{M}$ veratridine. The background $\mathrm{Na}$ flux did not vary in control cultures as a function of preincubation times in solutions lacking veratridine.

In contrast to NGF-treated cells, the $\mathrm{Na}$ influx in nontreated PC12 cells did not decrease with preincubation times of up to $1 \mathrm{hr}$ in veratridine-containing solutions (Fig. 2).

\section{Time course of Na uptake}

Figure 1, $A$ and $B$, shows the time courses of Na uptake in NGFuntreated and NGF-treated cells, respectively. Veratridine, 100 $\mu \mathrm{M}$, increases the rate of equilibration in both NGF-untreated and NGF-treated cells. The $t_{1 / 2}$ for this equilibration is reduced to 6-11 min in untreated cells and to 4-6 min in NGF-treated cells. Na uptake activated by veratridine is linear for $2 \mathrm{~min}$ with NGF-untreated cells and for $1 \mathrm{~min}$ with NGF-treated cells.

\section{Background Na permeability}

From the measurements of $\mathrm{Na}$ influx in the absence of drugs that activate the $\mathrm{Na}$ channel, it is possible to compare the background or resting $\mathrm{Na}$ permeability of the $\mathrm{PCl} 2$ membrane and to determine whether this parameter is modified by long-term exposure to NGF.

The average values for the background $\mathrm{Na}$ influx into NGFuntreated and NGF-treated PC1 2 cells from a large number of experiments were tabulated and are given in Table 1. Although the flux per cell is larger for NGF-treated cells, the calculated 


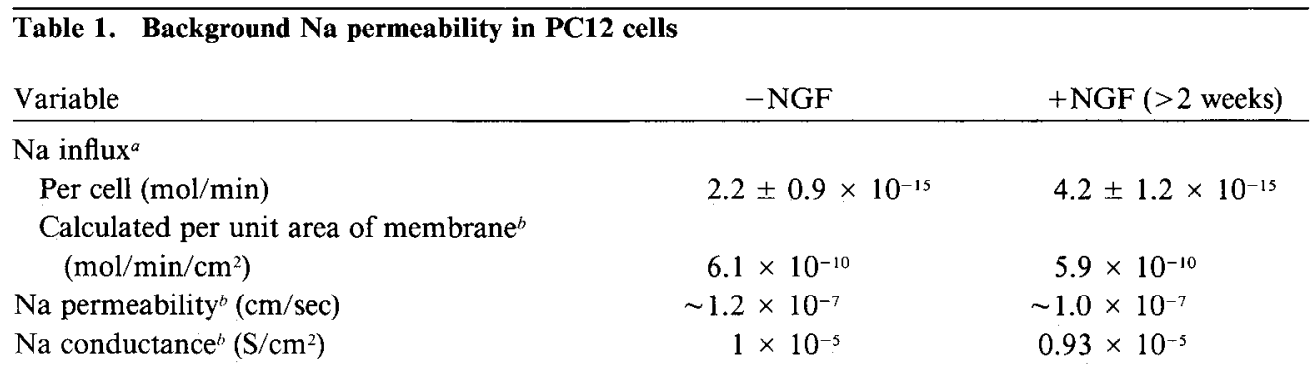

${ }^{a}$ Average flux data from nine 1 min and six 2 min assays for NGF-untreated cells, and eight 1 min assays and three 2 min assays for NGF-treated cells. All assays were carried out in $50 \mathrm{~mm}$ external Na.

${ }^{b}$ Calculated as described in the text.

flux per unit area of membrane is very similar or even slightly larger in NGF-untreated cells. This is based on a calculated membrane area of $350 \mu \mathrm{m}^{2}$ for NGF-untreated cells and 800 $\mu \mathrm{m}^{2}$ for NGF-treated cells (Rudy et al., 1982). These measurements assume that the cells are rounded and without processes, which is essentially valid for cultures grown on the polyornithine-coated substrate employed in our experiments. They also assume that the membrane surface is uniform and flat, which is not necessarily correct. Electron-microscopic observation of NGF-untreated cells shows the presence of multiple microvilla, which will tend to increase the membrane surface area. However, recent measurements by Connolly et al. (1984) of PC12 cell surface area based on electron-micrographic data produced values for the membrane area similar to those assumed here. In spite of any limitations in the estimate of membrane area, the results do suggest that the resting $\mathrm{Na}$ influx in PC12 cells is not significantly modified by long-term exposure to NGF.

Table 1 also shows the value of the background Na permeability. This was calculated from the obtained flux values with the Goldman-Hodgkin-Katz equation (Hodgkin and Katz, 1949):

$$
P_{\mathrm{Na}}=J_{\mathrm{Na}}(R T / V F) \frac{\exp (V F / R T)-1}{[\mathrm{Na}]_{\mathrm{o}}-\left[\mathrm{Na}_{\mathrm{i}}\right] \exp (V F / R T)}
$$

The application of this equation assumes, in addition to the assumptions inherent in its derivation, that the membrane potential remains constant (and hence the permeabilities and internal concentrations for all permeable ions) during the experiment. Except for small changes in membrane potential as a result of blockade of the Na pump for the short period of flux measurement, we can assume that the voltage remains constant and that the estimated permeability is valid. A membrane potential of $-40 \mathrm{mV}$ was used for the calculation (Rudy et al., 1982).
Values for the $\mathrm{Na}^{+}$permeability were also calculated from the half-time $\left(t_{1 / 2}\right)$ of isotope equilibration by

$$
\tau=V / P A
$$

where $V$ is cell volume, $P$ the permeability, and $A$ the surface area. Half-times of equilibrium were $19.7 \pm 5 \mathrm{~min}$ for NGFuntreated cells and $39 \pm 8 \mathrm{~min}$ for NGF-treated cells, which corresponds to $2 P_{\mathrm{Na}}$ of $2.3 \times 10^{-7}$ and $1.6 \times 10^{-7} \mathrm{~cm} / \mathrm{sec}$, respectively. Considering the different assumptions that go into calculating permeabilities from the equilibration time and from the constant field equation, these data are in good agreement with those in Table 1.

Sodium conductance (see Table 1) was calculated from the flux assuming an equilibrium potential for $\mathrm{Na}$ of $+40 \mathrm{mV}$. These data indicate little or no effect of NGF treatment on the background $\mathrm{Na}$ conductance of PC12 cells.

\section{Na channels in PC12 cells}

The increase in Na permeability caused by alkaloid neurotoxins such as veratridine and BTX has been used to detect the presence of $\mathrm{Na}$ channels in cell membranes. The data in Figure 1 indicate a substantial difference in stimulation by veratridine of the $\mathrm{Na}$ permeability in NGF-untreated versus NGF-treated PC1 2 cells.

Table 2 shows for a larger number of independent experiments the mean rate of $\mathrm{Na}^{+}$uptake by NGF-untreated and NGFtreated PC12 cells in the presence of $100 \mu \mathrm{M}$ veratridine. As shown in Figure 3, this is close to a maximally effective concentration of the drug. In the case of NGF-treated cells, the average rate was determined from 15 and $30 \mathrm{sec}$ flux experiments. In the case of NGF-untreated cells, the average is from $30 \mathrm{sec}$ and $1 \mathrm{~min}$ uptake assays. In each case, these times are well within the linear range. In various experiments, $100 \mu \mathrm{M}$ veratridine stimulated the flux by $1.3-$ to 1.9 -fold in NGF-

\begin{tabular}{|c|c|c|c|c|c|c|c|}
\hline Culture & $\begin{array}{l}\mathrm{Na}_{0} \\
(\mathrm{mM})\end{array}$ & $n$ & $\begin{array}{l}\text { Na resting flux } \\
(\mathrm{mol} / \mathrm{min} / \text { cell })\end{array}$ & $\begin{array}{l}\text { Na flux in the presence } \\
\text { of veratridine } \\
\text { (mol/min/cell) }\end{array}$ & $\begin{array}{l}\text { Veratridine- } \\
\text { induced flux } \\
\text { (mol } / \mathrm{min} / \text { cell) }\end{array}$ & $\begin{array}{l}\text { Veratridine- } \\
\text { induced } \\
\text { conductance } \\
\left(\mathbf{S} / \mathrm{cm}^{2}\right)\end{array}$ & $\begin{array}{l}\text { Conductance } \\
\text { per channel } \\
\text { (S) }\end{array}$ \\
\hline \multirow[t]{2}{*}{$-\mathrm{NGF}$} & 50 & 8 & $2.2 \pm 0.9 \times 10^{-15}$ & $3.5 \pm 1.1 \times 10^{-15}$ & - & - & - \\
\hline & 10 & 2 & $0.4 \pm 0.17 \times 10^{-15}$ & $1.0 \pm 0.31 \times 10^{-15}$ & $0.6 \times 10^{-15}$ & $1.3 \times 10^{-4}$ & $1.9 \times 10^{-13}$ \\
\hline \multirow[t]{2}{*}{$+\mathrm{NGF}$} & 50 & 6 & $3 \pm 0.6 \times 10^{-15}$ & $14.0 \pm 1.9 \times 10^{-15}$ & - & - & - \\
\hline & 5 & 2 & $0.5 \pm 0.08 \times 10^{-15}$ & $3 \pm 0.4 \times 10^{-15}$ & $2.5 \times 10^{-15}$ & $10.5 \times 10^{-4}$ & $2.0 \times 10^{-13}$ \\
\hline
\end{tabular}

Table 2. Veratridine-induced Na permeability in $\mathrm{PC12}$ cells

a Conductance at $200 \mathrm{~mm}$ external Na was calculated from net uptake due to veratridine stimulation from the measurements at 10 and $5 \mathrm{~mm} \mathrm{Na}$, as described in the text. 

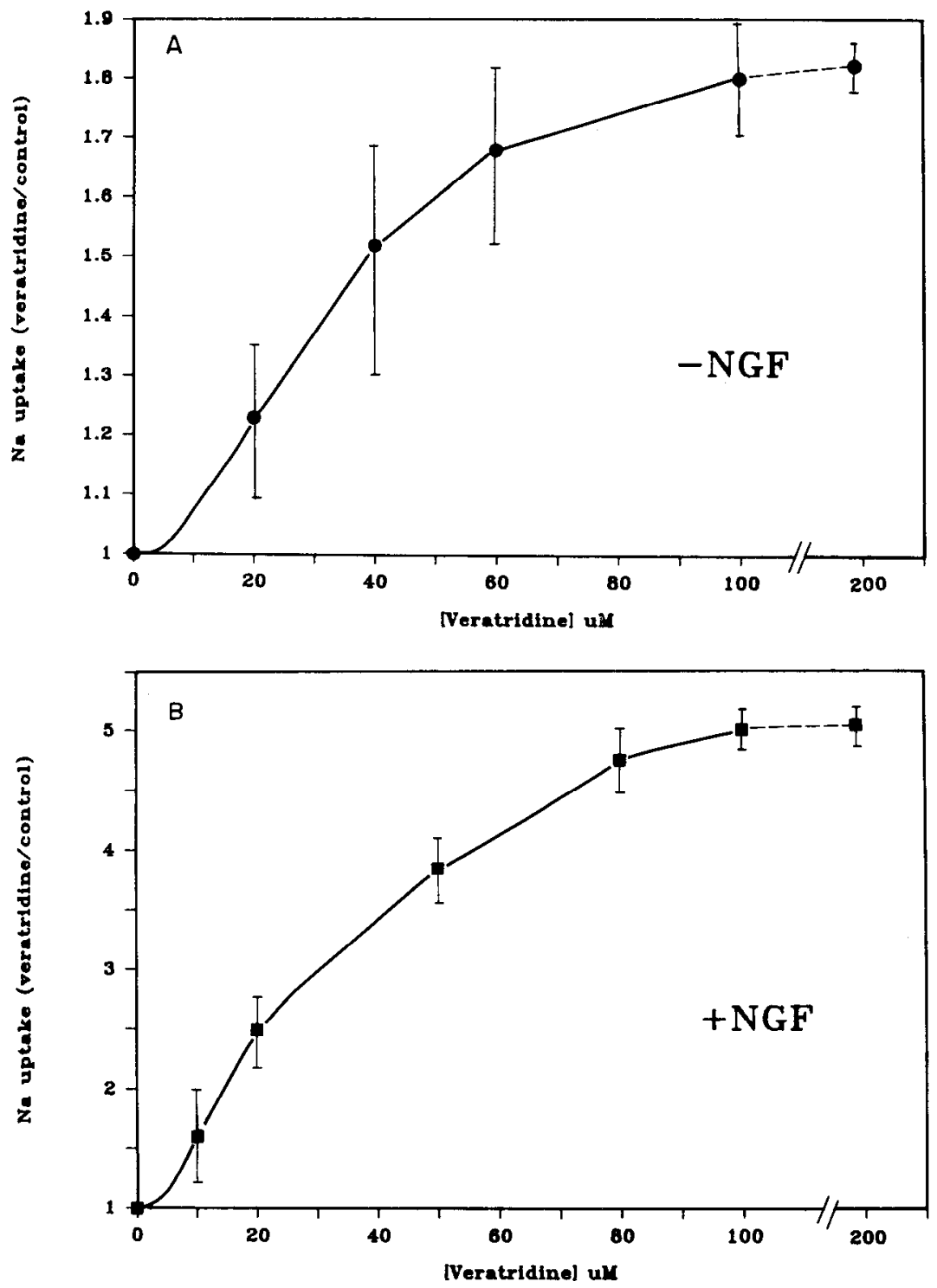

Figure 3. Concentration dependence of veratridine stimulation of ${ }^{22} \mathrm{Na}$ uptake in untreated $(A)$ and NGF-treated $(B)$ cells. Uptake is expressed as the ratio of ${ }^{22} \mathrm{Na}$ uptake in the presence of the indicated concentrations of veratridine to the uptake in control cultures incubated and assayed in the absence of veratridine. Cells were preincubated for $15 \mathrm{~min}$ ( $200 \mu \mathrm{M}$ veratridine), $20 \mathrm{~min}$ ( $80-100 \mu \mathrm{M}$ veratridine) or $30 \mathrm{~min}(0-$ $50 \mu \mathrm{M}$ veratridine) in Na-free medium. These preincubation times correspond to plateaus in incubation vs. stimulation determinations, such as that shown in Figure 2, which were carried out for each veratridine concentration. After incubation, ${ }^{22} \mathrm{Na}$ uptake was assayed for $1 \mathrm{~min}$ (-NGF cells) or $30 \mathrm{sec}(+\mathrm{NGF}$ cells). Data are given as means \pm SEM $(n=6)$.

untreated cells and by 3.9 - to 8 -fold in long-term NGF-treated cells.

These differences in responses of NGF-untreated and NGFtreated cells to veratridine are not due to differences in affinity for the drug. Figure 3 shows the dependence of channel activation on veratridine concentration in NGF-untreated and NGFtreated cultures. In each case, the titration curves show a similar affinity for veratridine. For the experiment shown in Figure 3, the apparent $K_{d}$ for veratridine is $36 \mu \mathrm{M}$ for NGF-untreated cells and $32 \mu \mathrm{M}$ for NGF-treated cells. For 3 independent experiments, the average $K_{d}$ was $42 \pm 5 \mu \mathrm{M}$ for NGF-untreated cells and $39 \pm 7 \mu \mathrm{M}$ for NGF-treated cells.

Differences in degree of stimulation by veratridine could result from 3 factors: (1) differences in single-channel conductance, (2) differences in the amount of time that the channel remains open in the presence of saturating concentrations of the drug, and (3) differences in the total number of channels. The total conductance $(G)$ due to activation of the $\mathrm{Na}$ channels in a cell can be expressed as

$$
G_{\mathrm{Na}}=g n f
$$

where $g$ is the conductance of a single $\mathrm{Na}$ channel activated by veratridine and $n$ is the total number of $\mathrm{Na}$ channels in the cell (assuming that at saturation all of the channels are activated for the fraction of time, $f$ ).

Table 2 also includes calculated membrane conductances after veratridine activation. The conductance values were determined from 2 flux experiments carried out at $5 \mathrm{~mm}$ external $\mathrm{Na}$ for NGF-treated cells and at $10 \mathrm{~mm}$ external $\mathrm{Na}$ for NGF-untreated cultures. At these $\mathrm{Na}$ concentrations, the ${ }^{22} \mathrm{Na}$ uptake was linear as a function of $\mathrm{Na}$ concentration in the presence of $100 \mu \mathrm{M}$ veratridine. Veratridine-stimulated flux was $0.6 \times 10^{-15} \mathrm{~mol} /$ $\mathrm{min} /$ cell for NGF-untreated cultures (average of 2 experiments) and $2.5 \times 10^{-15} \mathrm{~mol} / \mathrm{min} /$ cell for $\mathrm{NGF}$-treated cultures (average of 2 experiments). From these values we calculated a veratridine-induced increase in conductance assuming a membrane potential of $-30 \mathrm{mV}$ and reversal potentials of 0 for NGFuntreated cells and $-17 \mathrm{mV}$ for NGF-treated cells. Since $\mathrm{Na}$ channel conductance depends on $[\mathrm{Na}]$, the calculated value of the veratridine-induced conductance was extrapolated to that which would occur at $200 \mathrm{~mm}$ external $\mathrm{Na}$ and assuming Michaelis-Menten saturation behavior with a value of $370 \mathrm{~mm}$ for the $\mathrm{Na}$ concentration which gives half-maximal conductance (Hille, 1984). The results of this calculation, shown in Table 2 , 
Figure 4. Stimulation of ${ }^{22} \mathrm{Na}$ uptake into untreated (open symbols) and NGFtreated (closed symbols) PC1 2 cells by the indicated concentrations of BTX. Each set of symbols represents an independent experiment in which the values obtained from 6 separate cultures have been averaged. In each case, cells were preincubated for $30 \mathrm{~min}$ in $\mathrm{Na}^{+}$ free medium containing the corresponding concentration of BTX and then assayed for ${ }^{22} \mathrm{Na}$ uptake for $30 \mathrm{sec}$ ( + NGF cells) or 1 min (-NGF cells). Inset, Data plotted as the fraction of stimulated flux (value of uptake at a given [BTX] minus the control uptake, over the uptake at $10 \mu \mathrm{M}$ BTX minus the control uptake) as a function of the concentration of BTX. Filled squares, + NGF; open triangles, no NGF.

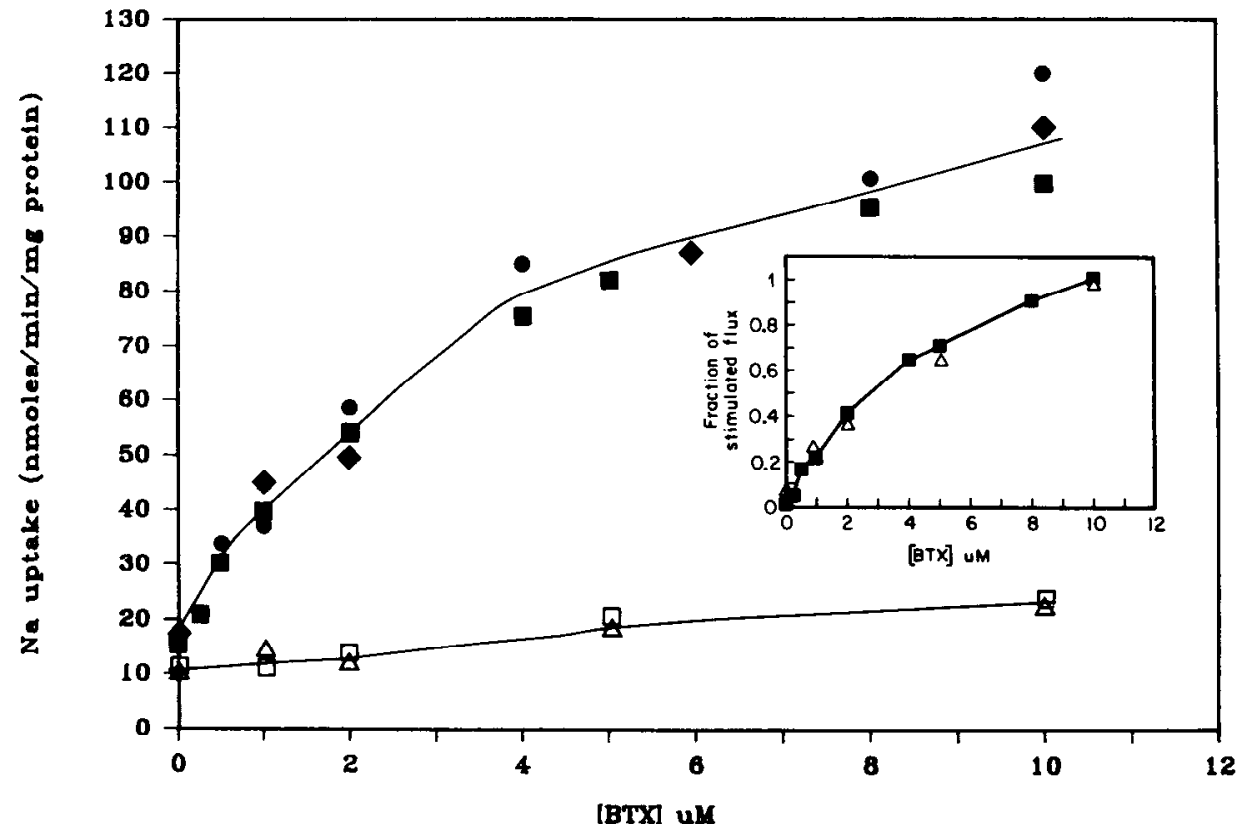

indicate an 8-fold increase in veratridine-induced conductance per unit area of membrane after NGF-treatment. This value corresponds well with the observed differences in STX binding (Rudy et al., 1982). If the calculated values of veratridine-induced conductance are divided by the number of channels determined from the STX binding data reported previously (Rudy et al., 1982), one obtains a figure for the conductance contributed per channel [product $g f$ in Eq. (3)]. A similar value is obtained for NGF-treated and untreated cells (see last column in Table 2).

\section{Activation of Na channels in PC12 cells by batrachotoxin and scorpion toxin}

BTX, an alkaloid produced by the Colombian frog Phyllobates aurotaenia, is a potent activator of $\mathrm{Na}$ channels (see Catterall, 1980). Catterall (1975a, b) has demonstrated that veratridine and BTX (as well as the alkaloids grayanotoxin and aconitine) act on the same site in the $\mathrm{Na}$ channel to produce persistent activation of ion flux. The 4 molecules compete with each other for the binding site and interact with this site with different affinities and result in various degrees of maximum channel activation (Catterall, 1975a, b). BTX is, in murine neuroblastoma cells, the most efficient of the 4 , producing a 2.7 -fold greater ion flux stimulation than veratridine. BTX also has the highest affinity, with a $K_{d}$ of $0.4 \mu \mathrm{M}$ in such cells.

At the concentrations at which BTX activates $\mathrm{Na}$ channels in neuroblastoma cells we found little activation of the $\mathrm{Na}$ permeability in NGF-untreated or NGF-treated PC12 cells. This was true whether or not the incubation and assay solutions contained $\mathrm{Ca}$ or whether the incubation solution contained 1 $\mathrm{mg} / \mathrm{ml}$ of BSA.

Figure 4 shows the concentration dependence of $\mathrm{Na}$ uptake stimulation by BTX in PC12 cultures. A 10-fold higher concentration than that reported to be required for neuroblastoma cells was necessary to obtain significant activation of $\mathrm{Na}$ channels in PC12 cells. Since BTX is not readily available in large amounts, it was not possible to use higher concentrations than those shown in Figure 4 and thus to reach saturation and determine the maximum flux activation attainable with this toxin.
Similar results with respect to concentration dependence of channel activation have been reported by Strichartz et al. (1983) and Bar-Sagi and Prives (1985) for cultured chick skeletal muscle cells.

In electric eel (Bartels-Bernal et al., 1977), repeated electrical stimulation of the plate is required to allow equilibration of BTX with a Na channel binding site. Activation of $\mathrm{Na}$ channels in this tissue can be accomplished by incubating the toxin in depolarizing solutions containing elevated $\mathrm{K}^{+}$. With PC12 cells, BTX was equally effective whether the cultures were preincubated in low-ionic-strength solution (see Materials and Methods) or in a similar solution in which sufficient sucrose was replaced by $\mathrm{KCl}$ so that the latter reached $50 \mathrm{~mm}$.

The data in Figure 4 show an approximate 5- to 6-fold difference (per mg protein) in flux stimulation by BTX in NGFtreated cells as compared to untreated cells. In the inset of this figure we have plotted the relative fraction of stimulated uptake at various concentrations of BTX. This plot allows a comparison of the stimulation of Na uptake by BTX in NGF-untreated and NGF-treated cells. As the plot indicates, the fraction of maximum stimulated uptake is similar as a function of BTX concentration before and after NGF treatment. This suggests that BTX has similar affinities for Na channels in both culture conditions. Despite not being able to reach saturation, it is clear from these data that the differences between NGF-untreated and NGF-treated cells obtained with BTX are within the range observed with veratridine.

Scorpion toxin, a polypeptide purified from the venom of the African scorpion Leiurus quinquestriatus, acts cooperatively with the alkaloid toxins that produce persistent activation of the $\mathrm{Na}$ channel (Catterall, 1975a, 1980). Scorpion toxin increases the affinity for alkaloid toxins and increases the maximum activation of the channel.

Figure 5, $A$ and $B$, shows the stimulation of channel activation by scorpion toxin at various concentrations of BTX for NGFuntreated and NGF-treated cells, respectively. Scorpion toxin shifts the concentration dependence of BTX activation for both NGF-untreated and NGF-treated cells. At saturation, BTX in the presence of scorpion toxin stimulated the flux 2.4-fold for 

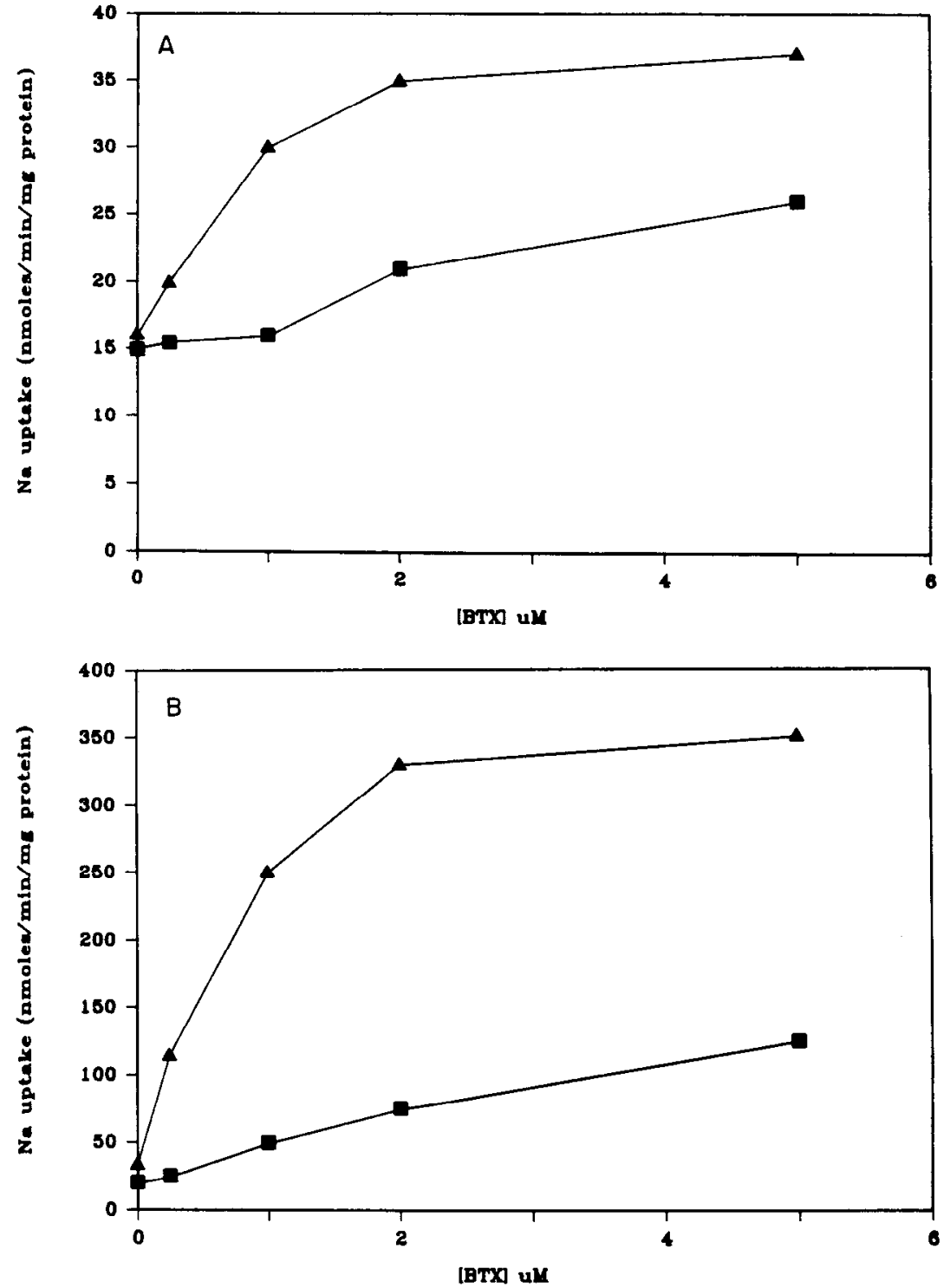

Figure 5. Stimulation of ${ }^{22} \mathrm{Na}$ uptake into untreated $(A)$ and $\mathrm{NGF}$-treated $(B)$ $\mathrm{PC} 12$ cells by BTX in the presence of scorpion toxin. Cells were incubated and assayed as in Figure 4 in the presence (triangles) or absence (squares) of $10 \mathrm{~nm}$ scorpion toxin and the indicated concentrations of BTX.
NGF-untreated cells and 10-fold for NGF-treated cells in the experiment shown in Figure 5. The ratio of stimulation of NGFtreated cells versus NGF-untreated cells is similar to that observed for veratridine or BTX alone. For both types of cultures, BTX stimulation of the flux in the presence of scorpion toxin has an apparent $K_{d}$ of $0.8 \mu \mathrm{M}$. These data indicate that for PC12 cells, scorpion toxin does not unmask BTX-insensitive Na channels as in chick developing muscle (Baumgold et al., 1983a, b).

\section{TTX block of Na uptake stimulated by alkaloid toxins}

Figure 6 shows the concentration dependence of the TTX block of BTX-stimulated Na uplake in NGF-untreated and NGFtreated cultures. For NGF-untreated cultures, the BTX-stimulated uptake was nearly totally inhibited by $50 \mathrm{~nm}$ TTX. In contrast, for NGF-treated cultures only about $70 \%$ of the BTXstimulated flux was blocked at this concentration of TTX. Most of the remaining BTX-stimulated uptake could be blocked in the NGF-treated cultures only by TTX concentrations greater than $1 \mu \mathrm{M}$. Such observations suggested the possible presence of 2 classes of TTX binding sites in NGF-treated cells. The data were, therefore, fitted with the curve-fitting program of Asyst (Module I-MacMillan Software) to

$$
\begin{aligned}
& \text { Flux }_{+\mathrm{TTX}} / \text { Flux }_{-\mathrm{TTX}}= \\
& \qquad A\left(\frac{K_{d 1}}{K_{d 1}+[\mathrm{TTX}]}\right)+B\left(\frac{K_{d 2}}{K_{d 2}+[\mathrm{TTX}]}\right)
\end{aligned}
$$

where $A$ represents the proportion of high-affinity binding sites with $K_{d}=K_{d 1}$, and $B$ that of low-affinity binding sites with $K_{d}=$ $K_{d 2}$.

In the case of NGF-untreated cells, the program dropped the second binding site (Fig. 6A). The data from 3 independent experiments yielded a mean $K_{d}$ value of $5.1 \pm 1.2 \mathrm{nM}$. For NGFtreated cells the best fit was obtained with 2 TTX-binding sites. Figure $6 B$ shows the fit to a single-binding-site equation and Figure $6 C$ shows the fit to Eq. (4). Clearly, the 2-binding-site curve fit the data better. Best-fit parameters were as follows: $A=0.8-0.85, K_{d 1}=7 \mathrm{nM}, B=0.2-0.15, K_{d 2}=400-800 \mathrm{~nm}$. The curve-fitting program could not distinguish between raising the proportion of $B$ between 15 and $20 \%$ simultaneously with changing $K_{d 2}$ between 800 and 400 nM. In all cases, a regression coefficient larger than 0.95 was obtained. An Eadie-Hofstee plot of the data is shown in Figure $6 D$. A strong deviation from linearity is observed. The smooth curve in Figure $6 D$ is the fit 

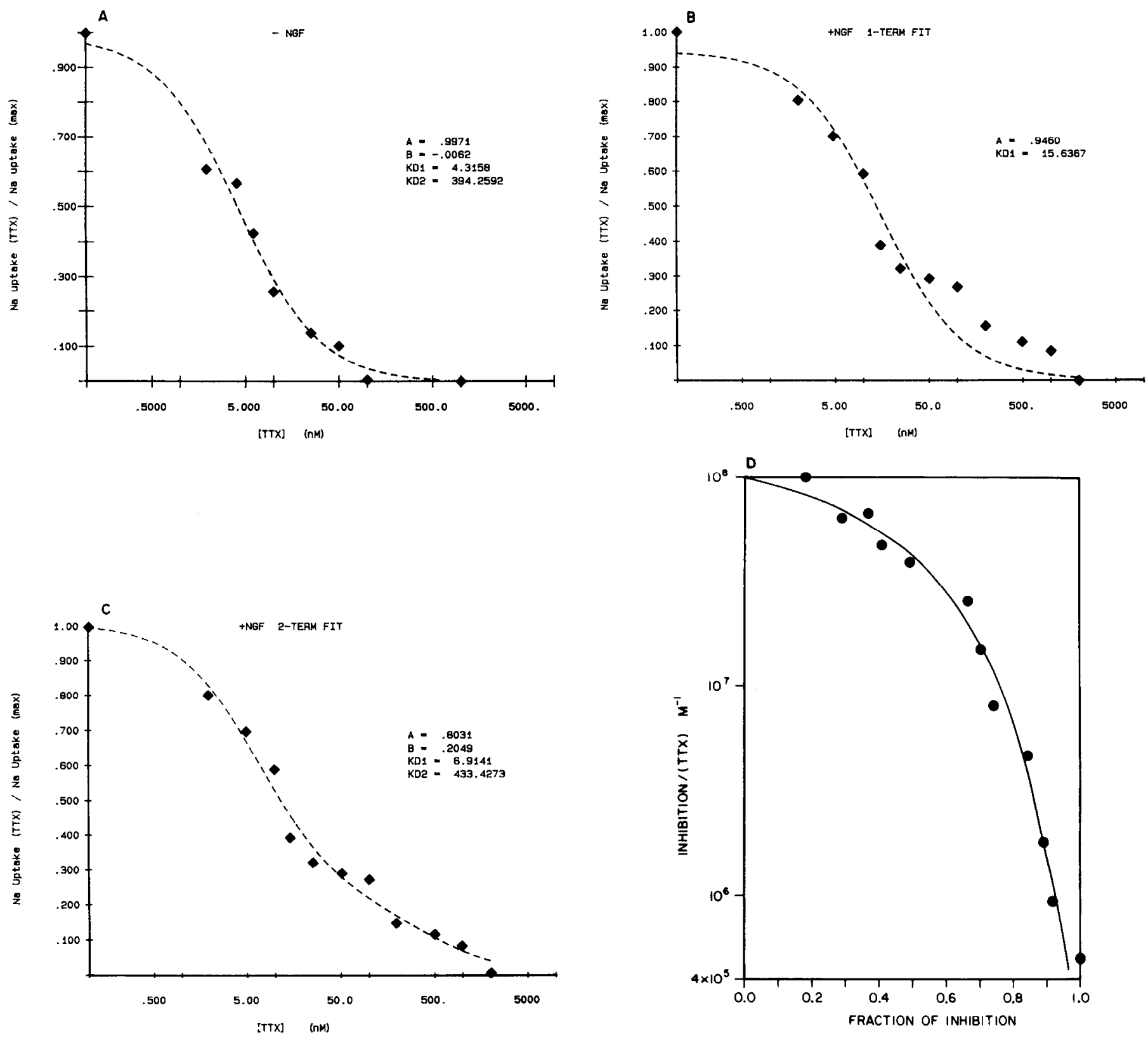

Figure 6. Blockade of the BTX-stimulated $\mathrm{Na}^{+}$flux in untreated $(A)$ and NGF-treated $(B-D)$ cells by various concentrations of TTX. Cells were preincubated for $30 \mathrm{~min}$ in $5 \mu \mathrm{M}$ BTX and the indicated concentrations of TTX and then assayed for ${ }^{22} \mathrm{Na}$ uptake for 30 sec ( + NGF cells) or 1 $\min$ (-NGF cells) in the presence of drugs. The curves shown in $A$ and $C$ are the best fit obtained with Asyst to Eq. (4) in the text; the curve shown in $B$ is the best fit to a single-binding-site equation; $D$ shows an Eadie-Hofstee plot of the data in $B$ and $C$ (see text).

to Eq. (4), with $A=0.85, B=0.15, K_{d 1}=7 \mathrm{nM}$, and $K_{d 2}=800$ nM. In a second independent repetition of the experiment shown in Figure $6, B$ and $C$, the best fits of the data were also obtained assuming 2 kinetically different binding sites for TTX with $A=$ $85-90 \%, K_{d 1}=6 \mathrm{nM}, B=10-15 \%$, and $K_{d 2}=500-800 \mathrm{nM}$. These experiments were carried out for cells grown in the presence of NGF for 3 weeks on collagen-coated dishes and then passaged into polyornithine-coated dishes $48 \mathrm{hr}$ before assay. Comparable results were also obtained for 1 experiment with cells that had been treated with NGF for 3 weeks on collagen but not passaged $(B=5-10 \%)$. We also measured the proportion of BTX- or veratridine-stimulated flux that is blocked by $50 \mathrm{~nm}$ TTX in a larger number of experiments. The amount of stimulated flux remaining at $50 \mathrm{nM}$ TTX was consistent for replicates within a single experiment but varied from experiment to experiment with values between 15 and $35 \%$. Assuming a $K_{d}$ of $7 \mathrm{~nm}$ for the high-affinity site, this represents a proportion of low-affinity sites ranging between 5 and $25 \%$ (mean, $14 \% \pm 9$; $n=9$ ).

In contrast to the above results, the BTX- or veratridinestimulated flux in NGF-untreated cultures was consistently entirely blocked at 50-100 nм TTX. Figure 7 shows an experiment with NGF-untreated cells with the data fitted to a single site with a $K_{d}$ for TTX of $6 \mathrm{nM}$. This figure includes the individual determinations of flux at 0,50,100, and $2000 \mathrm{~nm}$ TTX in order to show the actual scatter of the measurements. Also shown are thc individual uptakes for the control experiments in the absence of BTX. It is clear that all the stimulated flux is blocked at 50 


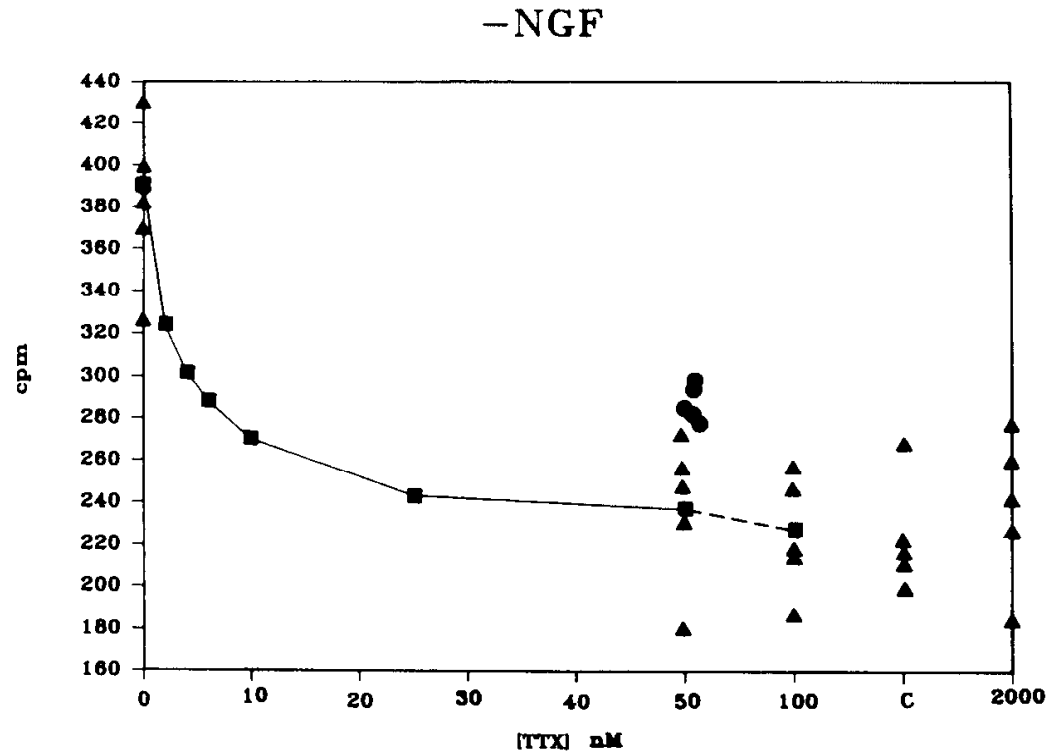

Figure 7. Blockade of the BTX-stimulated $\mathrm{Na}^{+}$flux in NGF-untreated PC12 cells by the indicated concentrations of TTX. Cells were preincubated and assayed as in Figure 6. Shown with closed squares are the averages of 5 replicate cultures at each TTX concentration; closed triangles at $0,50,100$, and 2000 nM TTX are the uptake values obtained for each replicate determination. Also shown (at $C$ ) are the uptake values of 5 cultures incubated and assayed in the absence of BTX or TTX. The dots above the experiment at $50 \mathrm{~nm}$ TTX are the values representing $10 \%$ of the stimulated flux of each of the determinations without TTX.
$100 \mathrm{~nm}$ TTX and that we should have been able to detect unblocked flux if NGF-untreated cells also contained more than $10 \%$ of low-affinity TTX binding sites.

It has been reported (Sherman et al., 1983; Frelin et al., 1984) that in developing muscle TTX-resistant Na channels differ from TTX-sensitive channels in their relative sensitivities to scorpion and anemone toxins. TTX-resistant channels are more sensitive to anemone toxin and less to scorpion toxin than TTX-sensitive channels. Figure 8 illustrates an experiment showing that this appears to be the case for NGF-treated PC12 cells. Figure $8 \mathrm{~A}$ compares the flux stimulation by scorpion toxin in NGF-treated cultures in the presence and absence of $100 \mathrm{~nm}$ TTX. Figure $8 B$ is a similar comparison using anemone toxin. In the absence of TTX, we estimate an apparent $K_{d}$ of $4 \mathrm{nM}$ for scorpion toxin and a $K_{d}$ of $70 \mathrm{~nm}$ for anemone toxin. In the presence of 100 nM TTX we estimate $K_{d} \mathrm{~s}$ for scorpion and anemone toxin of 30 and $5 \mathrm{nM}$, respectively.

\section{Excitable properties of TTX-resistant channels}

Electrophysiological studies were carried out to determine whether the TTX-resistant $\mathrm{Na}$ channels are capable of mediating excitability. In the absence of TTX, more than $80 \%$ of the cells studied produced action potentials such as those shown in Figure $9 A$ as described previously (Dichter et al., 1977; Rudy et al., 1982). Of 98 NGF-treated cells recorded in the presence of 100 nM TTX, 34 gave action potentials such as those shown in Figure $9 B$. These responses have a higher threshold and slower rate of rise than those recorded in the absence of TTX (Fig. 9A). No active responses were observed for any of the 89 recordings carried out in the presence of $2 \mu \mathrm{M}$ TTX. Thus, the TTX-resistant channels are capable of supporting active electrical responses. The heterogeneity in the excitability of cells noted in presence of $100 \mathrm{~nm}$ TTX could be due, among other factors, to differences in the number of unblocked channels at $100 \mathrm{~nm}$ TTX, variation within the cell population, or differences in leak or $\mathrm{K}^{+}$ currents.

\section{Discussion}

Background Na permeability. Within the limits of the assumptions made for calculations, the present results suggest that the passive permeability to $\mathrm{Na}^{+}$of the $\mathrm{PC} 12$ cell membrane remains the same after the cell is neuronally differentiated by long-term incubation with NGF. Excluding differences in the $\mathrm{Na}^{+}-\mathrm{K}^{+}$pump, which was blocked in these experiments, this result suggests that, on the average, similar Na permeating mechanisms remain operational after NGF-induced differentiation. These mechanisms may include $\mathrm{Na}^{+}-\mathrm{H}^{+}$exchange, $\mathrm{Na}^{+}-\mathrm{K}^{+}$and $\mathrm{Na}^{+}-\mathrm{Ca}^{2+}$ exchange, $\mathrm{Na}^{+}$-glucose and $\mathrm{Na}^{+}$-amino acid exchange, and other known $\mathrm{Na}^{+}$exchange mechanisms.

The calculated permeability of the PC12 membrane to $\mathrm{Na}^{+}$ when voltage-dependent $\mathrm{Na}$ channels are closed is within the range found for other cells. Electrical studies in nerve, muscle, and other cells show resting $P_{\mathrm{Na}}$ values of $10^{-8}-10^{-7} \mathrm{~cm} / \mathrm{sec}$ (Hille, 1984). These results compare well with a $P_{\mathrm{Na}}$ of $\sim 1-2 \times$ $10^{-7} \mathrm{~cm} / \mathrm{sec}$ found here. The resting electrical resistance of PC12 cells is $>500 \Omega \mathrm{cm}^{2}$ (Rudy et al., 1982). From this resistance a permeability of $<5 \times 10^{-6} \mathrm{~cm} / \mathrm{sec}$ can be calculated. Thus, a large fraction of the resting permeability of these cells is due to ions other than $\mathrm{Na}^{+}$, and, as with most neurons, it is most likely $\mathrm{K}^{+}$, which is the main ion that determines the resting potential of $\mathrm{PC} 12$ cells.

Modulation of Na channel number by veratridine. Incubation of NGF-treated PC12 cells with veratridine for more than 30 min was found to decrease the flux stimulation observed during assay. If this effect is due to ion movements, and since the incubation medium lacks $\mathrm{Na}$, the main ion changes that can take place in these cells upon $\mathrm{Na}$ channel activation are efflux of $\mathrm{K}^{+}$or entry of $\mathrm{Ca}^{2+}$. When the $\mathrm{Na}$ channel is opened by voltage, it allows $\mathrm{K}^{+}$passage with a selectivity of about $1 / 12$ over $\mathrm{Na}^{+}$and a similar selectivity for $\mathrm{Ca}^{2+}$ (Hille, 1984). Veratridineactivated channels are less selective than BTX- or voltage-activated channels (Tanaka et al., 1983). Wc thercfore propose that the modulation of $\mathrm{Na}$ channels that occurs upon prolonged exposure to veratridine is mediated via $\mathrm{K}^{+}$loss or $\mathrm{Ca}^{2+}$ entry through activated $\mathrm{Na}$ channels. These ionic changes will be greater in NGF-treated cells because they contain more channels. Microscopic observations show no gross alteration in cell morphology or cell number when cultures are maintained in incubation media containing up to $200 \mu \mathrm{M}$ veratridine for up to $2 \mathrm{hr}$. Although more experiments are required, these data 
Figure 8. Stimulation of the veratridine-induced $\mathrm{Na}^{+}$flux by scorpion toxin $(A)$ and anemone toxin $(B)$. NGFtreated PC12 cells were assayed in the presence (triangles) or absence (squares) of 100 nM TTX. Cells were preincubatcd for $30 \mathrm{~min}$ in the presence of 10 $\mu \mathrm{M}$ veratridine and the indicated concentrations of anemone or scorpion toxin (with or without TTX) and then assayed for ${ }^{22} \mathrm{Na}$ uptake for $30 \mathrm{sec}$ in the presence of drugs.
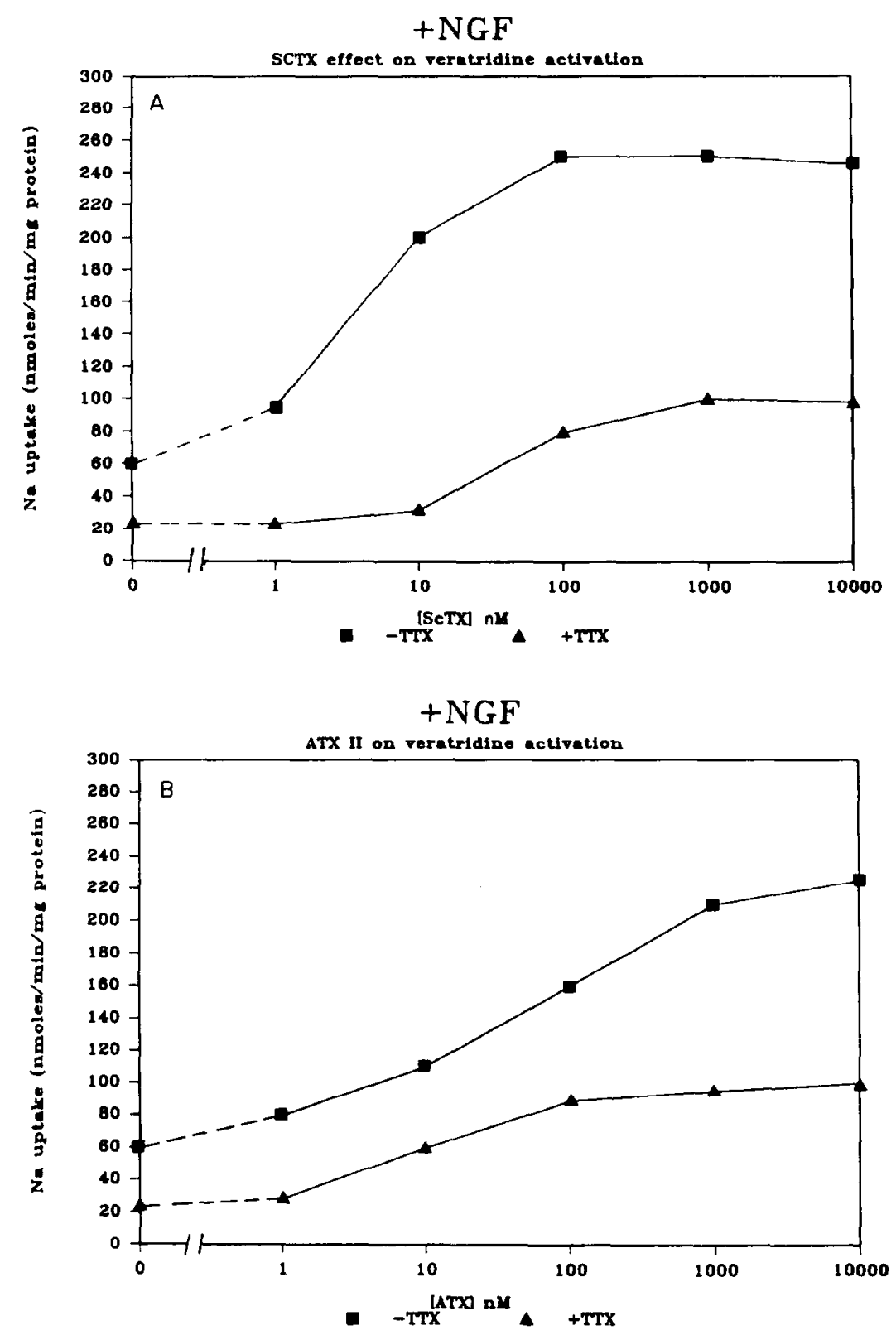

could be interpreted as evidence of down-regulation of Na channels, as observed in developing rat muscle cells (Sherman and Catterall, 1984). In the latter system, increases in cytosolic $\mathrm{Ca}^{2+}$ produce down-regulation of $\mathrm{Na}$ channels. Down-regulation of $\mathrm{Na}$ channels has also been observed in BTX-activated cultured chick muscle cells (Bar-Sagi and Prives, 1985).

\section{Voltage-dependent Na channels in PC12 cells}

The present experiments show that $\mathrm{Na}$ channels in PC12 cells are similar to those in other cells. In addition to being voltagedependent and in sufficient number after NGF treatment to allow the cell to fire action potentials, they contain 3 sites at which toxins can interact: a site that binds TTX and STX and at which drug binding leads to blockade of ion flux; a site that binds alkaloid toxins like veratridine and BTX which leads to persistent channel activation at voltages at which the channel is normally closed or inactivated; and a regulatory site that binds scorpion toxin, which acts cooperatively with alkaloid toxins (for reviews, see Catterall, 1980; Barchi, 1982). A fourth site that binds $\beta$-scorpion toxins has not been explored in $\mathrm{PC} 12$ cells.

Our previous studies on the interaction of $\mathrm{PC} 12 \mathrm{Na}$ channels with TTX and STX (Rudy et al., 1982) indicated that Na channels were qualitatively similar in PC12 cell membranes after long-term exposure to NGF, but that their number changes. A 15- to 25-fold increase in channel number per cell or 5-to 7 -fold per unit area of membrane was reported. The flux studies confirm and extend these findings. They demonstrate that the NGFinduced increase in STX binding represents an increase in functional TTX-sensitive Na channels, which are similar to those in NGF-untreated $\mathrm{PC} 12$ cells. In addition, there is the appearance of a subpopulation of channels with low affinity for TTX. The increase in functional TTX-sensitive channels is of similar magnitude to that found in the binding studies. Since the affinity of TTX-sensitive Na channels for STX is about 10 -fold lower than for TTX, we may expect that the determinations of STX binding in NGF-treated cells may include a small fraction of the population of TTX-resistant channels. If the $K_{d}$ of these 

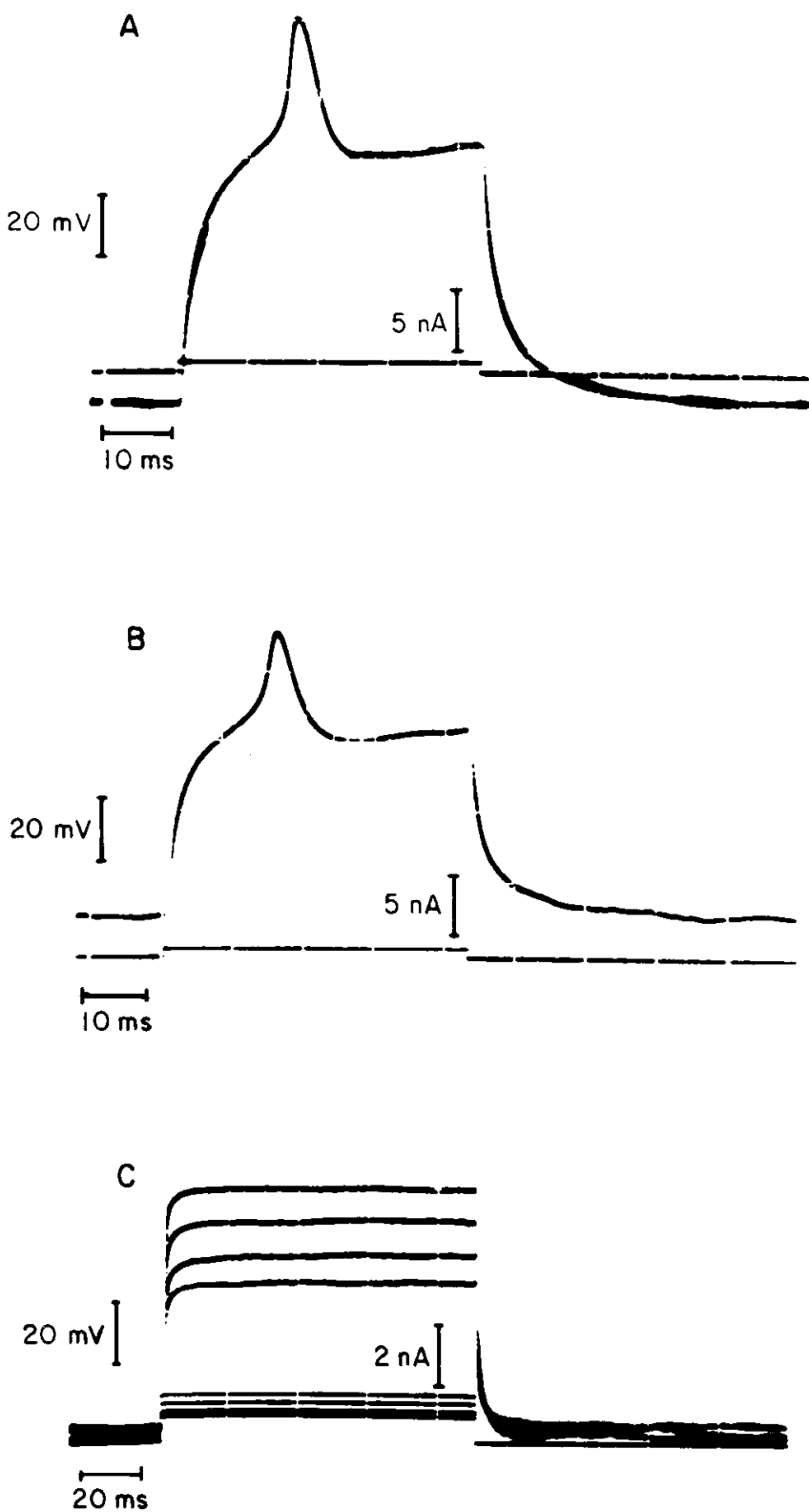

Figure 9. Electrical responses of $\mathrm{PC} 12$ cells obtained in the absence of TTX $(A)$, in the presence of $100 \mathrm{nM}$ TTX $(B)$, and in the presence of $2 \mu \mathrm{M} \operatorname{TTX}(C)$.

channcls for STX is also about 10-fold smaller than for TTX, as it is for TTX-sensitive channels, their $K_{d}$ would be around $60 \mathrm{nM}$. Since the maximum STX concentration used in the binding studies was $20 \mathrm{~nm}$, we would expect a maximum of $25 \%$ occupancy of these sites. Given the proportions of TTXresistant channels found, we would expect that only between 1 and $10 \%$ of the sites measured in the STX binding assays of NGF-treated cells correspond to TTX-resistant channels.

The NGF-induced increase in the number of TTX-sensitive channels seems not to include qualitative changes. Actions of various toxins and their affinities are similar before and after NGF exposure. We failed to observe the presence of "immature" channels such as those described by Baumgold et al. (1983a, b) in developing muscle. Although we have not compared the responses to veratridine and $\mathrm{B} \Gamma \mathrm{XX}$ of the TTX-sensitive and TTX-resistant $\mathrm{Na}$ channels, if differences do exist, they do not sccm to be substantial enough to significantly alter the doseresponse curves. Furthermore, we have observed the same range of fraction of flux remaining at 50 or 100 nм TTX in either veratridine or BTX.

The data obtained with veratridine are the most complete in order to consider the quantitative differences in channel number after NGF-induced differentiation. As explained in the Results, it is not possible to determine channel numbers from the flux experiments since the flux per channel depends on 2 as-of-yet undetermined factors, the single-channel conductance and the fraction of time that each channel is actually opened (and/or the fraction of channels modified by the toxin). The value obtained for the conductance per binding site represents a product of the actual single-channel conductance and the fraction of time that every channel is open in the presence of veratridine-see Eq. (3) above. Electrical measurements on veratridine-activated $\mathrm{Na}$ channels from rat brain membrancs incorporated into the lipid bilayers give a single-channel conductance of $10 \mathrm{pS}$ (Rudy, 1983 ) in $200 \mathrm{~mm} \mathrm{Na}$. Assuming the same single-channel conductance for veratridine-activated channels in PC12 cells, and given the value of $2 \times 10^{-13} \mathrm{~S}$ reported here (Table 2 ) for the product of single-channel conductance and probability of opening $(g f)$, we calculate a value of 0.02 for the fraction of time each channel remains open. This is similar to that which can be calculated from other flux studies (Catterall, 1977a, b). In spite of the uncertainties in the determination of the channel conductance, the fact that similar values for the conductance per binding site are obtained for NGF-untreated and NGFtreated cells (Table 2 ) suggests that the channels detected by STX binding assays can be equally activated in both types of cultures. We may therefore conclude that the functional studies reported here suggest similar increases in number of channels after NGF-induced neuronal differentiation as those found in our previous STX binding experiments. Furthermore, although for practical reasons we could not obtain full titration curves with BTX, the experiments with this toxin indicate differences in flux stimulation between untreated and NGF-treated cells similar to those obtained with veratridine. This suggests similar affinities for BTX, with and without NGF treatment, and similar differences in the number of BTX-activatable channels.

Since TTX-sensitive channels constitute the majority of channels in NGF-treated PC. 12 cells, they are probably the main sites responsible for electrical excitability. Taken together, our findings indicate that the NGF-regulated induction of electrical excitability in PC12 cells occurs via the insertion of greater numbers (i.e., about 5- to 7-fold) of TTX-sensitive Na channels per unit of membrane area.

\section{$T T X$-resistant channels in PC12 cells}

The second major effect of NGF noted here was the induction of TTX-resistant Na channels. The physiological significance of these sites is presently unclear. There are now several documented instances of TTX-resistant Na channels. For instance, the Na channels in the heart of several species, which are otherwise very similar to those in nerve and skeletal muscle, typically show a high resistance to TTX (i.e., Brown et al., 1981; Cohen et al., 1981). Na channels with low affinity for TTX have also been described in fetal mammalian muscle and in denervated adult muscle (Harris and Marshall, 1973; Kidokoro et al., 1975; Pappone, 1980). In muscle, the presence of $\mathrm{Na}$ channels with low affinity for TTX is associated with muscle development and innervation (Harris and Thesleff, 1971; Harris and Mar- 
shall, 1973; Sherman et al., 1983). After denervation of adult muscle, TTX-resistant Na channels appear that account for 25$30 \%$ of the Na conductance (Pappone, 1980). The TTX-resistant channels in denervated muscle disappear after innervation or after the muscle is treated with a crude spinal cord extract. The apparent $K_{d}$ for TTX of the TTX-resistant channels observed in NGF-treated PC12 cells, as well as the enhanced sensitivity of these sites to anemone toxin, suggests that they are similar to those found in developing muscle. However, additional studies are required to firmly establish this. Recently, Rogart et al. (1986) have demonstrated that mouse neuroblastoma cells can be selectively manipulated to express either exclusively TTXsensitive or both TTX-sensitive and TTX-resistant $\mathrm{Na}$ channels. On this basis, Rogart et al. have proposed that TTXresistant channels are associated with the development of uninnervated dendritic processes, which would in turn represent uninnervated postsynaptic membrane. Further experiments are required to determine whether these conclusions are relevant to our observations with PC12 cells. A TTX-resistant Na component has also been described for early stages in the development of the action potential in explants of dorsal root ganglia (i.c., Yoshida ct al., 1978). With time in culture these eventually become TTX sensitive.

In conclusion, NGF induces electrical excitability in PC12 cells by leading to an increase in the membrane density of functional TTX-sensitive Na channels. This probably takes place via an increase of the transcription of $\mathrm{Na}$ channel genes since the mRNA for the channel increases more than 10-fold after NGF treatment (T. Snutch, B. Rudy, L. A. Greene, H. Lester, and N. Davidson, unpublished observations). NGF also induces the presence of functional TTX-resistant Na channels. Further studies with this model system may shed light on the mechanism by which expression of functional $\mathrm{Na}$ channels is regulated during development, the possible significance of TTX-resistant $\mathrm{Na}$ channels, and the relationship between TTX-sensitive and -resistant Na channels.

\section{References}

Barchi, R. L. (1982) Biochemical studies on the excitable membrane sodium channel. Int. Rev. Neurobiol. 23: 69-101.

Bar-Sagi, D., and J. Prives (1985) Negative modulation of sodium channels in cultured chick muscle cells by the channel activator batrachotoxin. J. Biol. Chem. 260: 4740-4744.

Bartels-Bernal, E., L. T. Rosenberry, and J. W. Daly (1977) Effect of batrachotoxin on the electroplax of electric eel: Evidence for voltagedependent interaction with sodium channels. Proc. Natl. Acad. Sci. USA 74: 951-955.

Baumgold, J., J. B. Parent, and I. Spector (1983a) Development of sodium channels during differentiation of chick skeletal muscle in culture. I. Binding studies. J. Neurosci. 3: 995-1003.

Baumgold, J., J. B. Parent and I. Spector (1983b) Development of sodium channels during differentiation of chick skeletal muscle in culture. II. ${ }^{22} \mathrm{Na}$ uptake and electrophysiological studies. J. Neurosci. 3: 1004-1013.

Brown, A. M., K. S. Lee, and T. Powell (1981) Voltage-clamp and internal perfusion of single rat heart muscle cells. J. Physiol. (Lond.) 318: $455-477$.

Catterall, W. A. (1975a) Cooperative activation of action potential $\mathrm{Na}^{+}$ionophore by neurotoxins. Proc. Natl. Acad. Sci. USA 72: 17821786.

Catterall. W. A. (1975b) Activation of the action potential Na ionophore of cultured neuroblastoma cells by veratridine and batrachotoxin. J. Biol. Chem. 250: 4053-4059.

Catterall, W. A. (1976) Purification of a toxic protein from scorpion venom which activates the action potential $\mathrm{Na}$ ionophore. J. Biol. Chem. 251: 5528-5536.

Catterall, W. A. (1977a) Activation of the action potential $\mathrm{Na}^{+}$ionophore by neurotoxins. An allosteric model. I. Biol. Chem. 252:86698676.

Catterall, W. A. (1977b) Membrane potential-dependent binding of scorpion toxin to the action potential $\mathrm{Na}^{+}$ionophore. J. Biol. Chem. 252: $8660-8668$.

Catterall, W. A. (1980) Neurotoxins that act on voltage-sensitive sodium channels in excitable membranes. Annu. Rev. Pharmacol. Toxicol. 20: 15-43.

Cohen, C. J., B. P. Bean, T. J. Colatsky, and R. W. Tsien (1981) Tetrodotoxin block of sodium channels in rabbit Purkinje fibers: Interactions between toxin binding and channel gating. J. Gen. Physiol. 78: 383-411.

Connolly, J. L., S. A. Green, and L. A. Greene (1984) Comparison of rapid changes in surface morphology and coated pit formation of PC1 2 cells in response to nerve growth factor, epidermal growth factor, and dibutyryl cyclic AMP. J. Cell Biol. 98: 457-465.

Dichter, M. A., A. S. Tischler, and L. A. Greene (1977) Nerve growth factor-induced change in electrical excitability and acetylcholine sensitivity of a rat pheochromocytoma cell line. Nature 268: 501-504.

Frelin, C., P. Vigne, H. Schweitz, and M. Lazdunski (1984) The interaction of sea anemone scorpion ncurotoxins with tetrodotoxin. Resistant $\mathrm{Na}^{+}$channels in rat myoblasts. Mol. Pharmacol. 26: 7074.

Greene, L. A., and A. S. Tischler (1976) Establishment of a noradrenergic clonal line of rat adrenal pheochromocytoma cells which respond to nerve growth factor. Proc. Natl. Acad. Sci. USA 73: 24242428.

Greene, L. A., and A. S. Tischler (1982) PC12 pheochromocytoma cells in neurobiological research. Adv. Cell. Neurobiol. 3: 373-414.

Harris, J. B., and M. W. Marshall (1973) Tetrodotoxin-resistant action potentials in newborn rat muscle. Nature [New Biol.] 243: 191-192.

Harris, J. B., and S. Thesleff (1971) Studies on tetrodotoxin resistant action potentials in denervated skeletal muscle. Acta Physiol. Scand. 83: $382-388$.

Hillc, B. (1984) Ionic Channels of Excitable Membranes, Sinauer Assocs., Sunderland, MA.

Hodgkin, A. L., and B. Katz (1949) The effect of sodium ions on the electrical activity of the giant axon of the squid. J. Physiol. (Lond.) 108: $37-77$.

Kidokoro, Y., S. Heinemann, D. Schubert, B. L. Brandt, and F. G. Klier (1975) Synapse formation and neurotrophic effects on muscle cell lines. Cold Spring Harbor Symp. Quant. Biol. 40: 373-399.

Letourneau, P. C. (1975) Possible roles for cell to substratum adhesion in neuronal morphogenesis. Dev. Biol. 44: 77-91.

Mobley, W. C., A. Schenker, and E. M. Shooter (1976) Characterization and isolation of proteolytically modified nerve growth factor. Biochemistry 15: 5543-5551.

Okamoto, H. (1980) Binding of scorpion toxin to sodium channels in vitro and its modification by bungarotoxin. J. Physiol. (Lond.) 299: 507-520.

O'Lague, P. H., S. L. Huttner, C. A. Vandenberg, K. Morrison-Graham, and R. Horn (1985) Morphological properties and membrane channels of the growth cones induced in PC12 cells by nerve growth factor. J. Neurosci. Res. 13: 301-321.

Pappone, P. A. (1980) Voltage-clamp experiments in normal and denervated mammalian skeletal muscle fibres. J. Physiol. (Lond.) 306 : $377-410$.

Rogart, R. B., E. Geller, and V. B. Sapirstein (1986) Selective differentiation of mouse neuroblastoma cells can be used to express two different subtypes of sodium channel. Biophys. J. 49: 387a.

Rudy, B. (1983) Effects of batrachotoxin, veratridine and scorpion toxin on $\mathrm{Na}$ channels in lipid bilayers. Soc. Neurosci. Abstr. 9: 20.

Rudy, B., B. Kirschenbaum, and L. Greene (1982) Nerve growth factor-induced increase in saxitoxin binding to rat $\mathrm{PC} 12$ pheochromocytoma cells. J. Neurosci. 2: 1405-1411.

Sherman, S. J., and W. A. Catterall (1984) Electrical activity and cytosolic calcium regulate levels of tetrodotoxin-sensitive sodium channels in cultured rat muscle cells. Proc. Natl. Acad. Sci. USA 81: 262-266.

Sherman, S. J., J. C. Lawrence, D. J. Messner, K. Jacoby, and W. A. Catterall (1983) Tetrodotoxin-sensitive sodium channels in rat muscle cells developing in vitro. J. Biol. Chem. 258: 2488-2495. 
Strichartz, G., D. Bar-Sagi, and J. Prives (1983) Differential expression of sodium channel activities during the development of chick skeletal muscle cells in culture. J. Gen. Physiol. 82: 365-384.

Tanaka, J. C., J. F. Eccleston, and R. L. Barchi (1983) Cation sclcctivity characteristics of the reconstituted voltage-dependent sodium channel purified from rat skeletal muscle sarcolemma. J. Biol. Chem. 258: 7519-7526.
Yoshida, S., Y. Matsuda, and A. Samejima (1978) Tetrodotoxin-resistant sodium and calcium components of action potentials in dorsal root ganglion cells of the adult mouse. J. Neurophysiol. 41: 10961106. 